\title{
ISOLATION AND CHARACTERIZATION OF TRICHOMONAS VAGINALIS FERREDOXIN*
}

\author{
by \\ THOMAS E. GORRELL, NIGEL YARLETT" and MIKLOS MÜLLER ${ }^{21}$
}

The Rockefeller University, Box 282, 1230 York Avenue, New York, NY 10021, USA

"Present address: Department of Microbiology, University College, Newport Road, Cardiff CF2 ITA, Wales, UK

"Guest Investigator and Rask-Ørsted Fellow in the Department of Physiology of the Carlsberg Laboratorium in 1965-1966

*Dedicated with admiration and gratitude to Dr. Heinz Holter on the occasion of his 80 th birthday

Keywords: Trichomonas vaginalis, ferredoxin, hydrogenosome, pyruvate: ferredoxin oxidoreductase, hydrogenase, metronidazole, iron-sulfur proteins

\begin{abstract}
A ferredoxin was purified from the anaerobic protozoon Trichomonas vaginalis. The protein had a molecular weight of 12,000 as assessed by sodium dodecyl sulfate-polyacrylamide gel electrophoresis, gel filtration and amino acid analysis. The protein contained seven 1/2-cystine (cystine plus cysteine) residues and one tyrosine, and lacked tryptophan. Chemical analysis and spectral properties of the ferredoxin indicated the presence of a [2Fe-2S] cluster. The complex optical spectrum of the native ferredoxin had peaks at 310 and $450 \mathrm{~nm}$ and shoulders near 415 and $550 \mathrm{~nm}$. The molar absorbance of the protein at $450 \mathrm{~nm}$ was $8,000 \mathrm{M}^{-1} \times \mathrm{cm}^{-1}$. The EPR spectrum of reduced ferredoxin had two features at $g$ values of 2.02 and 1.94 and revealed axial symmetry. Results of subcellular fractionation studies indicated the ferredoxin to be a major iron-sulfur protein of the cells and to be located in the hydrogenosome. The ability of the ferredoxin to function as an electron carrier was demonstrated by its reduction by pyruvate:ferredoxin oxidoreductase and hydrogenase as detected by EPR spectroscopy and by its stimulation of metronidazole reduction by these enzymes. These observations implicate ferredoxin as an important electron transport component in hydrogenosomes of $T$, vaginalis.
\end{abstract}

Abreviations: $\mathbf{P}_{1 / 2}=$ half saturation parameter; SDS-PAGE = sodium dodecyl sulfate-polyacrylamide gel electrophoresis. 


\section{INTRODUCTION}

Metabolic pathways, in which ferredoxin-like electron transport components participate, are assumed to play a significant role in various anaerobic protozoa which contain no mitochondria (16). Low molecular weight iron-sulfur proteins with characteristic properties of ferredoxin were isolated, however, only from two protozoan species, Entamoeba histolytica and Tritrichomonas foetus. These ferredoxins accept electrons from homologous pyruvate: ferredoxin oxidoreductases $(14,20)$. In this paper we report the isolation and partial characterization of a [2Fe-2S] ferredoxin from Trichomonas vaginalis. Similarly to other protozoan ferredoxins this protein is likely to be a natural electron transport component in the energy metabolism of $T$. vaginalis. These results were presented in part at the 83rd Annual Meeting of the American Society for Microbiology (New Orleans, LA, March 6-11, 1983) and at the 36th Annual Meeting of the Society of Protozoologists (New York, NY, 20 to 24 June, 1983; T.E. GoRRELL, N. YARLETT and M. MULLER, J. Protozool. 30, 4A-5A, 1983).

\section{EXPERIMENTAL PROCEDURES}

\subsection{Organism}

Trichomonas vaginalis, ATCC 30001, was grown for one day at $37^{\circ} \mathrm{C}$ in a tryptone-yeast extract-maltose medium supplemented with 10 $\mu \mathrm{g} \mathrm{ml}^{-1}(170 \mu \mathrm{M})$ iron and $10 \%$ heat inactivated horse serum (4). Iron was added as ferrous ammonium sulfate dissolved in 5-sulfosalicylic acid. For cell fractionation experiments, cells were collected from 31 cultures. For purification of ferredoxin, larger amounts of material were collected from three 151 batches of cultures and then stored at $-20{ }^{\circ} \mathrm{C}$ until processed, within 3 weeks (14).

\subsection{Purification of ferredoxin}

Ferredoxin was purified from whole cells of T. vaginalis by deoxycholate treatment and subsequent ion exchange chromatography and gel filtration (14). In detail, the cells were resuspended to $30 \mathrm{mg} \times \mathrm{ml}^{-1}$ protein in a solution containing a final concentration of $50 \mathrm{mM}$-Tris base (adjusted to $\mathrm{pH} 8.0$ with $\mathrm{HCl}$ ) and 10 $\mathrm{mg} \times \mathrm{ml}^{-1}$ sodium deoxycholate. The solution was kept at $4{ }^{\circ} \mathrm{C}$ for 20 hours, then centrifuged at $50000 \mathrm{rpm}$ for $45 \mathrm{~min}$ at $4{ }^{\circ} \mathrm{C}$ (Ti70 rotor in a Sorvall OTD 75 ultracentrifuge). After centrifugation the tube contained a clear golden supernatant with a turbid layer on top and a dark pellet at the bottom of the tube. Ferredoxin was purified from the clear supernatant solution by ion exchange chromatography on DEAE cellulose and two cycles of gel filtration on Sephadex G-75. The details of these steps were similar to those used for $T$. foetus ferredoxin (14). Purity and molecular weight of the final product were assessed by gel filtration and sodium dodecyl sulfate-polyacrylamide gel electrophoresis (SDS-PAGE) (14).

\subsection{Chemical analysis}

For amino acid analysis, apoferredoxin was prepared by precipitation of the native protein with $920 \mathrm{~mm}$-trichloracetic acid (23). A sample of the apoferredoxin was oxidized with performic acid (15) for determination of total cysteine plus cystine. Samples were hydrolysed for 20 hours in $6 \mathrm{~N} \mathrm{HCl}$ and $1 \mu \mathrm{l} \times \mathrm{ml}^{-1}$ phenol. Amino acid composition was determined in a Dionex D-500 amino acid analyzer (Dionex Inc., Sunnyvale, CA). Protein iron, and labile sulfur were determined as described (14).

\subsection{Spectroscopy}

Ultraviolet-visible spectra of $T$. vaginalis ferredoxin were recorded in a Cary 210 spectrophotometer. Samples in quartz cuvettes $(1 \mathrm{~cm}$ light path) sealed with rubber stoppers were made anaerobic by repeated evacuation and filling with $\mathrm{O}_{2}$-free $\mathrm{N}_{2}$. Dithionite was added with a syringe through the stopper (14). Samples for EPR spectroscopy were prepared in a titration vessel (5) at $30{ }^{\circ} \mathrm{C}$. The solution was flushed with air or $\mathrm{O}_{2}$-free $\mathrm{N}_{2}$. After $5 \mathrm{~min}$, samples were transferred with a syringe into quartz tubes and rapidly frozen by immersion into an isopentanemethylcyclohexane $(5: 1, \mathrm{v} / \mathrm{v})$ freezing mixture chilled with liquid $\mathrm{N}_{2}$. The tubes were stored in liquid $\mathrm{N}_{2}$ until spectra were recorded on an E 109 spectrometer (Varian Associates, Palo 
Alto, CA). The conditions used were: microwave frequency $9.3 \mathrm{GHz}$; modulation frequency 100 $\mathrm{kHz}$; modulation amplitude $12.5 \mathrm{G}$; scanning rate $250 \mathrm{G} \mathrm{min}^{-1}$; time constant $0.25 \mathrm{~s}$. Spectra were recorded at various temperatures (10 to $30 \mathrm{~K}$ ) and at a wide range of microwave power $(0.01$ to $200 \mathrm{~mW})$. The half saturation parameter $\left(\mathbf{P}_{1 / 2}\right)$ of EPR signals was determined by the method of BLUM and OHNISHI (2).

\subsection{Subcellular fractionation}

Subcellular localization of ferredoxin was determined by differential centrifugation of a cell free homogenate of $T$. vaginalis under anaerobic conditions. The homogenization medium was $225 \mathrm{~mm}$-sucrose supplemented with $100 \mathrm{mM}$ potassium phosphate $\mathrm{pH} 8.0$ and $20 \mathrm{~mm}-\beta$-mercaptoethanol. The following fractions were separated: nuclear, large cytoplasmic granule, small cytoplasmic granule and non-sedimentable cytoplasmic fraction. Conditions of centrifugation were as described (10), except that the large granule fraction was obtained by centrifugation at a higher centrifugal force $(7750 \mathrm{rpm}$ for $10 \mathrm{~min}$ ). Malate dehydrogenase (decarboxylating), $\beta-\mathrm{N}$-acetylglucosaminidase, acid phosphatase, and NADH oxidase were assayed spectrophotometrically in all fractions (9). EPR spectra of fractions reduced with 2 mM-sodium dithionite were also recorded.

\subsection{Hydrogenosomal extracts}

Extracts were prepared under anaerobic conditions in an anaerobic glove chamber (Coy Laboratory Products, Ann Arbor, MI) as described (14). Fractions enriched in large cytoplasmic granules, including hydrogenosomes, were solubilized by deoxycholate treatment and subjected to ion exchange chromatography. In detail, a $10 \mathrm{ml}$ fraction was diluted with the same volume of a solution containing $100 \mathrm{mM}$-potassium phosphate $\mathrm{pH} 8.0,20 \mathrm{mg} \times \mathrm{ml}^{-1}$ sodium deoxycholate, $20 \mathrm{~mm}-\beta$-mercaptoethanol, and $20 \mathrm{~mm}$-sodium pyruvate. This material was centrifuged at $50,000 \mathrm{rpm}$ for $45 \mathrm{~min}$ at $4{ }^{\circ} \mathrm{C}$ and the clear golden solution obtained was applied to a jacketed column at $4{ }^{\circ} \mathrm{C}$ of DEAE Sephacel $(1.5 \times 5 \mathrm{~cm})$. Excluded material con- tained the hydrogenosomal enzymes pyruvate:ferredoxin oxidoreductase and hydrogenase. Reduction of metronidazole by these enzymes was determined by the procedure described earlier (14). Aliquots of the excluded material were stored under $\mathrm{H}_{2}$ atmosphere at $4{ }^{\circ} \mathrm{C}$.

\section{RESULTS}

3.1. Purification and chemical composition

Our experience with purification of $T$. foetus ferredoxin (14) indicated that extraction of

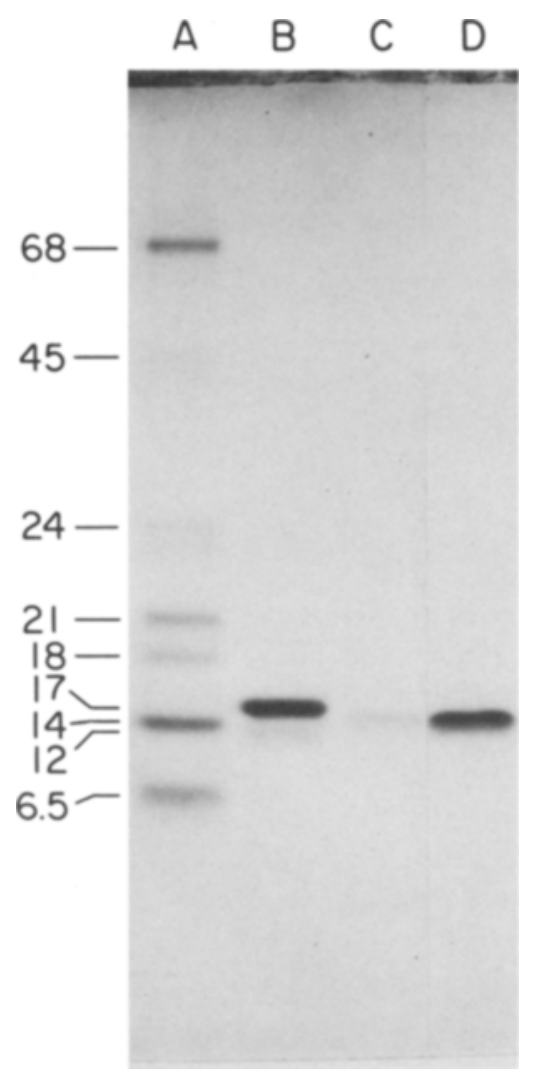

Figure 1. SDS-PAGE of T. vaginalis ferredoxin on a 12 to $18 \%$ polyacrylamide gradient gel. Molecular weight markers: $(A)$ bovine serum albumin $\left(\mathbf{M}_{r}=\right.$ $68,000)$, ovalbumin $(45,000)$, trypsinogen $(24,000)$, soy bean trypsin inhibitor $(21,000)$, lactalbumin $(18,000)$, lysozyme $(14,000)$ and aprotinin $(6,500)$ (B) myoglobin $(17,000)$ and cytochrome $c(12,000)$. $T$. vaginalis ferredoxin: (C) $5 \mu \mathrm{g}$; (D) $25 \mu \mathrm{g}$. 
Table I.

Amino Acid Composition of Trichomonas vaginalis Ferredoxin

\begin{tabular}{|c|c|c|c|}
\hline \multirow{2}{*}{ Amino Acid } & \multicolumn{2}{|c|}{ Amount Detected ${ }^{a}$} & \multirow{2}{*}{$\begin{array}{l}\mathrm{mol} \\
\left.\mathrm{mol} \mathrm{M}_{\mathrm{r}} \quad 12,000^{\mathrm{t}}\right)\end{array}$} \\
\hline & Not oxidized & Oxidized & \\
\hline Cys & - & 5.44 & 7 \\
\hline Asx & 9.53 & 12.23 & 13 \\
\hline Thr & 5.10 & 5.97 & 7 \\
\hline Ser & 2.53 & 2.85 & 3 \\
\hline GIx & 10.65 & 12.62 & 15 \\
\hline Pro & 1.32 & 1.51 & 2 \\
\hline Gly & 7.76 & 9.03 & 11 \\
\hline Ala & 9.96 & 11.29 & 14 \\
\hline Cys & 2.45 & - & - \\
\hline Val & 5.10 & 6.05 & 7 \\
\hline Met & 1.06 & - & 1 \\
\hline Ile & 2.92 & 3.47 & 4 \\
\hline Leu & 7.25 & 8.11 & 10 \\
\hline Tyr & 0.74 & - & 1 \\
\hline Phe & 3.69 & 3.78 & 5 \\
\hline His & 0.98 & - & 1 \\
\hline Lys & 7.71 & 9.00 & 11 \\
\hline Arg & 1.05 & 1.25 & 1 \\
\hline Trp & - & - & $0^{\mathrm{cal}}$ \\
\hline
\end{tabular}

whole cell suspensions under aerobic conditions gives good recovery thus subcellular fractionation and strict anaerobic techniques are not necessary. After an initial bulk DEAE-cellulose treatment of deoxycholate-solubilized cell suspensions, the protein could be purified to apparent homogeneity by two cycles of Sephadex G75 gel filtration. The affinity of $T$. vaginalis ferredoxin to DEAE-cellulose was slightly greater than that of $\mathrm{T}$. foetus ferredoxin. Consequently, the ferredoxin had to be eluted with $300 \mathrm{~mm}$, instead of $200 \mathrm{~mm}, \mathrm{NaCl}$.

The $T$. vaginalis ferredoxin preparations obtained were essentially pure since they gave only a single protein peak in the second cycle of gel filtration and a single protein band by SDSPAGE (Figure 1). From $13 \mathrm{~g}$ of starting protein $6.5 \mathrm{mg}$ of purified ferredoxin was obtained which indicates it represented at least $0.05 \%$ of total cell protein.

The protein isolated had a low molecular weight as indicated by its comigration with cytochrome $c$ during gel filtration on Sephadex G-75 (not shown) and SDS-PAGE (Figure 1). Both methods gave an apparent $\mathbf{M}_{r}$ of 12,000 . Anomalous migration of ferredoxins during gel filtration and SDS-PAGE has been reported, however, which casts some uncertainty on molecular weight values obtained by these methods alone $(7,12,14)$.

Results of amino acid analysis are presented in Table I. Assumingthe presence of one tyrosine residue per molecule, again an approximate $M_{r}$ of 12,000 could be calculated. The seven $1 / 2-$ cystine (cystine plus cysteine) residues detected could accommodate either a [2Fe-2S] or a [4Fe$4 \mathrm{~S}$ ] cluster characteristic of ferredoxins or one iron atom characteristic of rubredoxin (18). Spectral properties of the native protein suggested that the protein lacked tryptophan (see below).

The purified protein had approximately equal 
Table II.

Composition of Trichomonas vaginalis and Spinacea oleracea ferredoxins

\begin{tabular}{|c|c|c|c|c|c|c|c|}
\hline Ferredoxin & $\mathrm{A}_{458} / \mathrm{A}_{280}$ & $\begin{array}{l}\text { Protein } \\
\mathrm{mg} \times \mathrm{ml}^{-1}\end{array}$ & Protein & $\begin{array}{l}\text { Iron } \\
\text { nmol } \times \mathrm{ml}^{-1}\end{array}$ & $\begin{array}{l}\text { Labile } \\
\text { Sulfur }\end{array}$ & $\begin{array}{l}\text { Iron } \\
\text { mol } \times \mathrm{mol}^{-1}\end{array}$ & $\begin{array}{l}\text { Labile } \\
\text { Sulfur } \\
\text { ferredoxin }\end{array}$ \\
\hline \multicolumn{8}{|l|}{$\begin{array}{l}\text { T. vaginalis } \\
\left(\mathrm{M}_{\mathrm{r}} 12,000\right)\end{array}$} \\
\hline Sample A & 0.69 & $1.0 \pm 0.12^{\mathrm{a})}$ & 82.5 & $145 \pm 10$ & $172 \pm 4$ & 1.76 & 2.09 \\
\hline Sample B & 0.80 & $1.9 \pm 0.11$ & 158 & $317 \pm 13$ & $350 \pm 19$ & 2.01 & 2.21 \\
\hline $\begin{array}{l}\text { S. oleracea } \\
\left(M_{r} 12,000\right)\end{array}$ & - & $\begin{array}{r}1.45 \pm 0.15 \\
{[2.00}\end{array}$ & $\begin{array}{l}120.9 \\
166.8]^{b \prime}\end{array}$ & $318.7 \pm 6.2$ & $308.7 \pm 8.7$ & $\begin{array}{r}2.64 \\
{[1.90}\end{array}$ & $\begin{array}{l}2.55 \\
1.85]^{\text {b(a) }}\end{array}$ \\
\hline
\end{tabular}

a) Amounts per $\mathrm{ml}$ represent means + standard deviations obtained in two determinations.

b) Values within brackets were based on estimation of protein content by absorbance measurements at 420 nm.

amounts of iron and labile sulfur (Table II). In view of numerous difficulties (18) that can be encountered in determination of protein, iron and labile sulfur we also analysed samples of Spinacea oleracea ferredoxin. The amounts of iron and labile sulfur detected in $T$. vaginalis ferredoxin were similar to those detected in $\mathrm{S}$. oleracea ferredoxin indicating the presence of one $[2 \mathrm{Fe}-2 \mathrm{~S}]$ cluster if a $\mathrm{M}_{\mathrm{r}}$ of 12,000 is assumed.

\subsection{Spectral properties}

Solutions of the native protein were redorange. The complex optical spectrum of $\mathrm{T}$. vaginalis ferredoxin had peaks at $310 \mathrm{~nm}$ and $450 \mathrm{~nm}$ and shoulders near $415 \mathrm{~nm}$ and 550 $\mathrm{nm}$ (Figure 2). In contrast to most [2Fe-2S] ferredoxins (18) which show two peaks in the $415-460 \mathrm{~nm}$ region, only one peak was observed in this region of the spectrum of $T$. vaginalis ferredoxin similarly to $T$. foetus ferredoxin (14). Assuming an $\mathrm{M}_{\mathrm{r}}$ of 12,000 , fresh preparations of $T$. vaginalis ferredoxin had a molar absorbance at $450 \mathrm{~nm}$ of $8000 \mathrm{M}^{-1} \times \mathrm{cm}^{-1}$ which is close to that of other [2Fe-2S] ferredoxins (18).

The absorbance of the native ferredoxin at $280 \mathrm{~nm}$ was $10,000 \mathrm{M}^{-1} \times \mathrm{cm}^{-1}$. As noted by KERESZTES-NAGY (6), a significant part of the absorbance of ferredoxins at $280 \mathrm{~nm}$ is due to iron, because of the low content in aromatic amino acid residues. The molar absorbance at $280 \mathrm{~nm}$ of $T$. vaginalis and T. foetus (14)

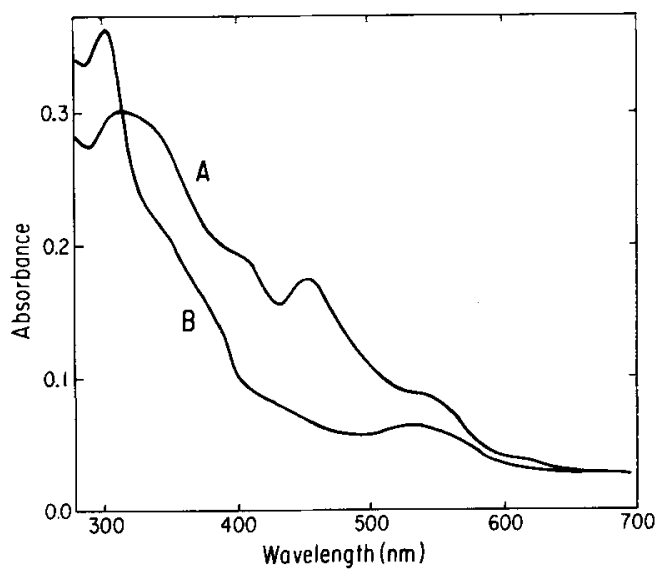

Figure 2. Absorption of native (A) and reduced (B) $T$. vaginalis ferredoxin. The ferredoxin solution ( 31 $\mu \mathrm{M}$ protein) was rendered anaerobic in a sealed quartz cuvette (10 $\mathrm{mm}$ optical path). After recording the spectrum of the native protein, the solution was reduced with $150 \mu \mathrm{M}$-sodium dithionite.

ferredoxins is similar to that of bovine adrenodoxin which contains a single tyrosine residue and no tryptophan $(22,24)$, indicating that trichomonad ferredoxins lack tryptophan. The $\mathrm{A}_{458} / \mathrm{A}_{280}$ ratio which is regarded to reflect the purity of holoferredoxins, was 0.8 in a fresh preparation, a value similar to those reported for bovine adrenodoxin (14) and T. foetus ferredoxin (22), and larger than a value of 0.4 to 0.5 found for other [2Fe-2S] ferredoxins with 


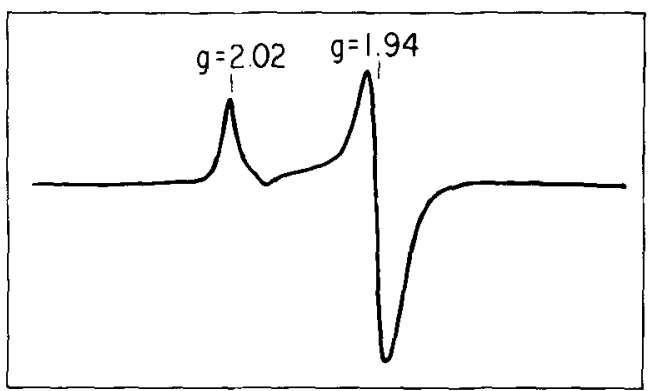

Figure 3. EPR spectrum at $25 \mathrm{~K}$ of $\mathrm{T}$. vaginalis ferredoxin $(31 \mu \mathrm{M})$ reduced with $150 \mu \mathrm{M}$-sodium dithionite. Microwave power $-0.5 \mathrm{~mW}$; receiver gain $-5 \times 10^{3}$.

larger numbers of tyrosine and tryptophan residues $(6,7,8,24)$. In older samples of $T$. vaginalis ferredoxin lower ratios were observed, presumably corresponding to a loss of iron-sulfur clusters (6).

$T$. vaginalis ferredoxin could be reduced with dithionite (Figures 2 and 3). Upon reduction, $\mathrm{A}_{450}$ decreased by $60 \%$ and the shoulder at 550 $\mathrm{nm}$ became a broad peak. When air was admitted to the reduced sample, the red-orange color reappeared and the spectrum was identical to that of the native protein. The EPR spectrum of the native ferredoxin was featureless (not shown) whereas the spectrum of the protein reduced with dithionite had a complex shape of an axial symmetry with $\mathrm{g}_{/ /}=2.02$ and $\mathrm{g}_{\perp}=$ 1.94 (Figure 3). No spectral distortion appeared over a broad range of temperature and microwave power. At $25 \mathrm{~K}$, the value of $P_{1 / 2}$ of the $\mathrm{g}=1.94$ signal was approximately $1.5 \mathrm{~mW}$ whereas this feature was already saturated at $0.01 \mathrm{~mW}$ in spectra recorded at $10 \mathrm{~K}$. These results are consistent with the presence of a [2Fe-2S] cluster (21) with virtually axial symmetry as seen for [2Fe-2S] clusters in hydroxylasetype ferredoxins (18).

\subsection{Subcellular distribution}

EPR spectroscopy of dithionite reduced subcellular fractions indicated that the ferredoxin was enriched in hydrogenosomes(Figures 4 and 5). Spectra of the hydrogenosome enriched frac-

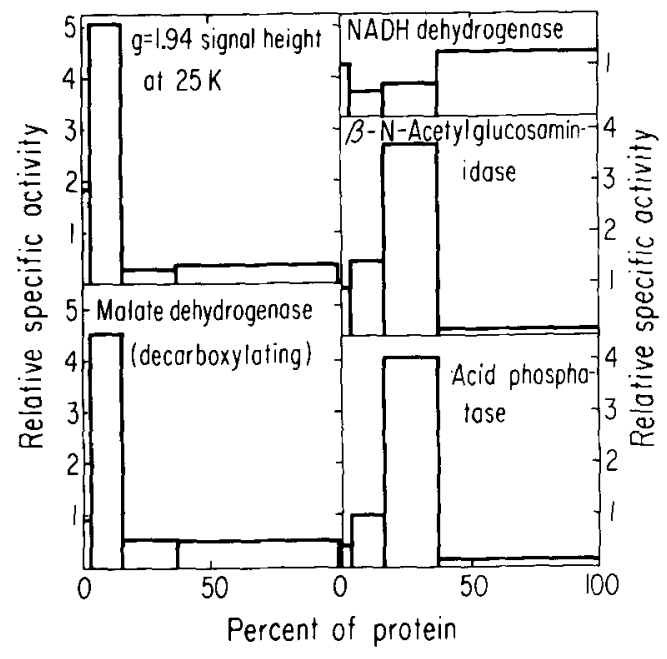

Figure 4. Distribution of the component giving the $\mathrm{g}=1.94 \mathrm{EPR}$ signal and of marker enzymes after differential centrifugation of a homogenate of $T$. vaginalis. Relative specific activity was plotted against cumulative percentage of protein recovered in each fraction. In the graph the direction from left to right corresponds to increasing centrifugal field. The far right-hand block represents the final supernatant. Percentage recoveries were $104 \%$ for EPR signal height at $\mathrm{g}=1.94,100 \%$ for malate dehydrogenase (decarboxylating), $86 \%$ for NADH dehydrogenase, $100 \%$ for acid phosphatase, $95 \%$ for $\beta$ - $\mathrm{N}$-acetylglucosaminidase and $106 \%$ for protein. Samples for EPR studies were reduced by $2 \mathrm{mM}$-sodium dithionite and spectra were recorded at $25 \mathrm{~K} 0.5 \mathrm{~mW}$.

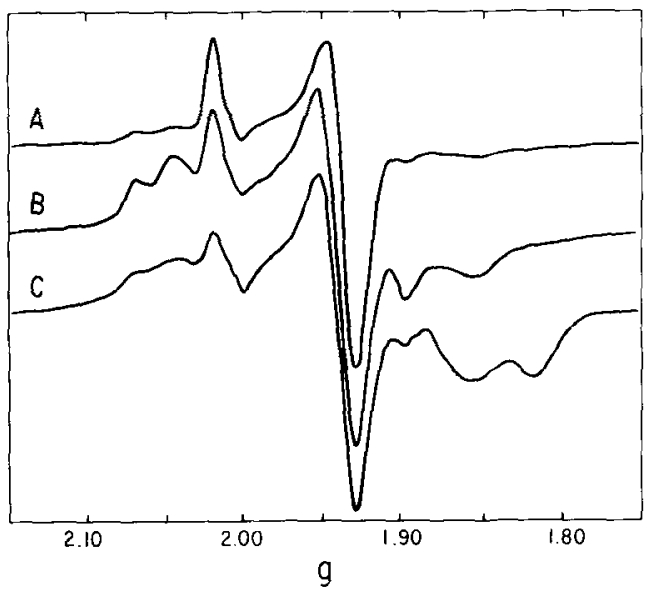

Figure 5. EPR spectra of a dithionite reduced large granule fraction ( $21 \mathrm{mg} \times \mathrm{ml}^{-1}$ protein). Conditions for spectroscopy: (A) $25 \mathrm{~K}, 0.5 \mathrm{~mW}$, and $4 \times 10^{3}$ gain; (B) $25 \mathrm{~K}, 50 \mathrm{~mW}$, and $2 \times 10^{3}$ gain; and (C) $10 \mathrm{~K}, 2 \mathrm{~mW}$, and $4 \times 10^{3}$ gain. 
T.E.GOR RELL et al.: Trichomonas vaginalis ferredoxin

Table III.

Effect of ferredoxin on enzyme activities of hydrogenosomal extracts of Trichomonas vaginalis

\begin{tabular}{|c|c|c|c|}
\hline \multirow{2}{*}{ Enzyme } & \multirow{2}{*}{$\begin{array}{l}\text { Ferredoxin } \\
(\mu \mathrm{M})\end{array}$} & \multicolumn{2}{|c|}{ Electron Acceptor ${ }^{a}$} \\
\hline & & Metronidazole & Methyl Viologen \\
\hline \multirow{3}{*}{$\begin{array}{l}\text { Pyruvate:ferredoxin } \\
\text { oxidoreductase }\end{array}$} & none & 46 & 5840 \\
\hline & 4 & 171 & 5530 \\
\hline & 8 & 394 & - \\
\hline \multirow[t]{3}{*}{ Hydrogenase } & none & $<10$ & 7680 \\
\hline & 4 & 105 & 8050 \\
\hline & 8 & 175 & - \\
\hline
\end{tabular}

tion recorded at $25 \mathrm{~K}$ and $0.5 \mathrm{~mW}$ had two dominant features at $\mathrm{g}$ values of 1.94 and 2.02 characteristic of the ferredoxin (Figure 5). Moreover, the relaxation behavior of the feature at $g=1.94$ was similar to that of the ferredoxin. At $25 \mathrm{~K}$, the value of $P_{1 / 2}$ of the signal at $g=$ 1.94 in spectra of the large granule fraction was approximately $1.5 \mathrm{~mW}$ and this feature was already saturated at $0.01 \mathrm{~mW}$ when spectra were recorded at $10 \mathrm{~K}$. Spectra of the large granule fraction, however, became more complex upon changes in power or temperature. The most complex spectra were seen at $10 \mathrm{~K}$ when they contained a feature with an unusual $\mathrm{g}$ value of 1.82. These complex spectra presumably reflected the overlapping signals of several components as reported for the analogous spectra of T. foetus (17). Nevertheless, the ferredoxin could be selectively detected by recording at 25 $\mathrm{K}$ and $0.5 \mathrm{~mW}$.

The distribution profile of the EPR signals obtained at $25 \mathrm{~K}$ and $0.5 \mathrm{~mW}$, and at $10 \mathrm{~K}$ and $2 \mathrm{~mW}$ (data not shown) matched closely the profile of the hydrogenosomal marker enzyme, malate dehyrogenase (decarboxylating) (Figure 4), and was quite distinct from the marker enzymes for other subcellular components. The distribution patterns observed for various marker enzymes are similar to those reported earlier (10) but the hydrogenosomal marker enzyme, malate dehydrogenase (decar- boxylating), showed a higher relative specific activity which can be attributed to the use of increased centrifugal force in preparing the large granule fraction.

It has been estimated that hydrogenosomes represent about $5-10 \%$ of the protein in $\mathrm{T}$. vaginalis cells (10). Based on this value and the amount of ferredoxin recovered from cells, the ferredoxin represents at least $0.5 \%$ of the protein in the organelle. Assuming the hydrogenosomes have $20 \%$ protein on a weight per volume basis, the concentration of ferredoxin in the organelle is at least $80 \mu \mathrm{M}$.

\subsection{Enzymatic reduction}

Purified T. vaginalis ferredoxin served as an electron acceptor for homologous hydrogenosomal enzymes, pyruvate:ferredoxin oxidoreductase and hydrogenase. Reduction of ferredoxin could be detected by EPR spectroscopy of DEAE treated hydrogenosomal extract. EPR spectra of the hydrogenosomal extract incubated with dithionite (spectra not shown) or pyruvate and cofactors necessary for pyruvate:ferredoxin oxidoreductase activity had a small feature at $g=2.00$ and lacked a feature at $g=1.94$ indicating efficient removal of the ferredoxin by the DEAE treatment (Figure 6). Supplementation of the protein extract with purified ferredoxin gave more complex spectra 


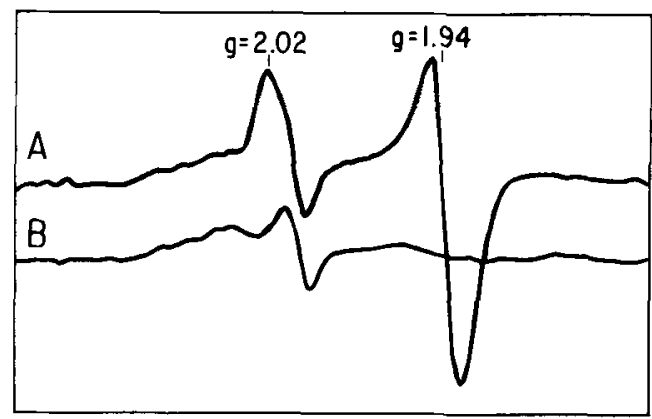

Figure 6. EPR spectra at $25 \mathrm{~K}$ of a DEAE treated hydrogenosomal extract $T$. vaginalis $\left(2.1 \mathrm{mg} \times \mathrm{ml}^{-1}\right.$ protein), supplemented with pyruvate, coenzyme $A$ and $\beta$-mercaptoethanol, and $4.0 \mu \mathrm{M}$-ferredoxin (A) or no ferredoxin (B). Microwave power $-0.5 \mathrm{~mW}$; receiver gain $-16 \times 10^{3}$.

with dominant features at $\mathrm{g}=2.02$ and 1.94 characteristic of ferredoxin.

Reduction of ferredoxin by pyruvate:ferredoxin oxidoreductase and hydrogenase was also demonstrated by its effects on metronidazole reduction by hydrogenosomal extracts (Table III). Metronidazole is a nitroheterocyclic drug that chemically oxidizes reduced ferredoxin (11). In the absence of ferredoxin, metronidazole was reduced at low rates. Added ferredoxin stimulated the rate of reduction. The extent of stimulation by ferredoxin was proportional to the amount of ferredoxin added. Saturation was not observed even when $20 \mu \mathrm{M}$-ferredoxin was added. The limited amount of purified protein available precluded the use of concentrations comparable to the assumed concentration of the ferredoxin in the hydrogenosome. Stimulation of metronidazole reduction by $T$. vaginalis ferredoxin wascomparable to that by S. oleracea or Clostridium pasteurianum ferredoxin (data not shown). The extent of the stimulation of metronidazole reduction by pyruvate:ferredoxin oxidoreductase in hydrogenosomal extracts was less than reported earlier for the analogous activity in $T$. foetus (14), possibly due to the higher rate of metronidazole reduction by ferredoxin depleted hydrogenosomal extracts of $\mathrm{T}$. vaginalis. Although ferredoxin stimulated metronidazole reduction, no stimulation of methyl viologen reduction was observed indicating that this compourd accepts electrons directly from the enzyme.

\section{DISCUSSION}

Our results show that $T$. vaginalis contains a [2Fe-2S] ferredoxin. The nature of the ironsulfur clustcr was deduced from the results of chemical analysis and the spectral properties of the protein. The optical spectrum of the native ferredoxin had most features characteristic of [2Fe-2S] clusters but no peak near $425 \mathrm{~nm}$. As also observed for $T$. foetus ferredoxin and adrenodoxin (22), the $A_{458} / A_{280}$ ratio of $T$. vaginalis ferrodoxin was greater than reported for most other $[2 \mathrm{Fe}-2 \mathrm{~S}]$ ferredoxins. The higher ratio (purity index) is probably due to the low number of aromatic residues in trichomonad ferredoxins and bovine adrenodoxin $(6,8,14,24)$. The spectrum of reduced $T$. vaginalis ferredoxin had the broad peak at $550 \mathrm{~nm}$ present in spectra of several hydroxylase-type ferredoxins (18), which in contrast to these proteins persisted as a shoulder in the spectrum of native $T$. vaginalis ferredoxin. EPR spectroscopy of the reduced protein indicated that the iron-sulfur cluster had a virtually axial symmetry similar to hydroxylase-type ferredoxins and lacked the rhombic distortion of chloroplast-type ferredoxins (18). Trichomonad ferredoxins differ in their spectral properties from E.histolytica ferredoxin which is reported to contain 8 atoms of iron and labile sulfur per molecule suggesting the presence of two [4Fe-4S] clusters (20).

The association of the ferredoxin with hydrogenosomes and its ability to react with hydrogenosomal oxidoreductases, pyruvate:ferredoxin oxidoreductase and hydrogenase, indicates its possible role in hydrogen production in $\mathrm{T}$. vaginalis $(13,19)$. The hydrogenosomal electron transport system of $T$. vaginalis appears quite similar to that of $T$. foetus. Hydrogenosomes of both organisms have the same type of ferredoxin. EPR spectra of hydrogenosomal fractions of both organisms (17) are similar but in $T$. vaginalis an additional feature was seen at a $g$ value of 1.82 . In view of the reports that pyruvate:ferredoxin oxidoreductase and hydrogenase from bacteria have [4Fe-4S] clusters which are paramagnetic in the reduced state (1, 3 ), it is probable that iron-sulfur clusters associated with these enzymes contributed to the EPR spectra of the hydrogenosomes.

The results support the idea that hydrogen 
production by trichomonad hydrogenosomes is similar to the process in anaerobic fermentative bacteria such as clostridial species (16). In these bacteria a 2 [4Fe-4S] ferredoxin serves as electron carrier between pyruvate:ferredoxin oxidoreductase and hydrogenase (25). Although a similar type of ferredoxin was purified from another anaerobic protozoon (20), this organism lacks hydrogenase and hydrogenosomes. In contrast, trichomonad hydrogenosomes have a ferredoxin with a [2Fe-2S] cluster showing that the protozoan electron transport system involved in $\mathrm{H}_{2}$ production differs in this respect from the bacterial system.

\section{ACKNOWLEDGEMENTS}

We thank Drs. T. OHNISHI, R. Lo BRUTTO and Dr. P. BLACKBURN and M. POSPISCHIL for assistance in obtaining and interpreting EPR spectra and amino acid analysis respectively, E. Roman (G.D. Searle \& Company, San Juan, PR) for providing metronidazole and J. LIEBELSON, N. YARLETT nee CORBaCIOGLU and DOMINIQUE COTTON for superb technical support. Supported by US Public Health Service Grants AI 11942 and RR 07065. TEG was supported by a US Public Health Service Training Grant GM 07245.

\section{REFERENCES}

1. Adams. M.W.W L.E. Mortenson \& J.S. Chen: Hydrogenase. Biochim. Biophys. Acta 594, $105-$ 176 (1981)

2. Blum, H. \& OHNISHI: Electron spin relaxation of the electron paramagnetic resonance spectra of cytochrome c. Biochim. Biophys. Acta 621, 9-18 (1980)

3. Cammack, R., L. Kerscher \& D. Oesterhelt: A stable free radical intermediate in the reaction of 2-oxoacid:ferredoxin oxidoreductases of Halobacterium halobium. FEBS Lett. 118, 271-273 (1980)

4. DiAmOND, L.S: The establishment of various trichomonads of animals and man in axenic cultures. J. Parasitol. 43, 488-490 (1957)

5. Dutron, P.L.: Redox potentiometry. Determination of midpoint potentials of oxidation-re- duction components of biological electron-transfer systems. Methods Enzymol. 54, 411-435 (1978)

6. Keresztes-Nagy. S. \& E. Margoliash: Preparation and characterization of alfalfa ferredoxin. $J$. Biol. Chem. 241, 5955-5966 (1966)

7. Kimura, T. \& K. Suzuki: Components of the electron transport system in adrenal steroid hydroxylase. Isolation and properties of non-heme iron protein (adrenodoxin). J. Biol. Chem. 242, 485491 (1967)

8. KNOELL, H.E. \& J. KNAPPE: Escherichia coli ferredoxin, an iron-sulfur protein of the adrenodoxin type. Eur. J. Biochem. 50, 245-252 (1974)

9. LindMARK, D.G. \& M. MUlleR: Hydrogenosome, a cytoplasmic organelle of the anaerobic flagellate, Tritrichomonas foetus, and its role in pyruvate metabolism. J. Biol. Chem. 248, 7724-7728 (1973)

10. Lindmark, D.G., M. Muller \& H. Shio: Hydrogenosomes in Trichomonas vaginalis. J. Parasitol. 61, 552-554 (1975)

11. LINDMARK, D.G.\& M. MULler: Antitrichomonad action, mutagenicity, and reduction of metronidazole and other nitroimidazoles. Antimicrob. Agents Chemother. 10, 476-482 (1976)

12. Lode, E.T.. C.L. Murray \& J.C. Rabinowitz: Apparent oxidation-reduction potential of Clostridium acidi-urici ferredoxin. Effect of $\mathrm{pH}$, ionic strength, and amino acid replacements. J. Biol. Chem. 251, 1683-1687 (1976)

13. MACK.S.R. \& M. MULLER: End products of carbohydrate metabolism in Trichomonas vaginalis. Comp. Biochem. Physiol. 67B, 213-216 (1980)

14. Marczak, R. T.E. Gorrell \& M. Muller: Hydrogenosomal ferredoxin of the anaerobic protozoon, Tritrichomonas foetus. J. Biol. Chem. 258, 12427-12433 (1983)

15. MOORE, $S$ : On the determination of cystine as cysteic acid. J. Biol. Chem. 238, 235-237 (1963)

16. Muller, M.: The hydrogenosome. Symp. Soc. Gen. Microbiol, 30, 127-142 (1980)

17. Ohnishi. T.. D. Lloyd, D.G. Lindmark \& M. MULLER: Respiration of Tritrichomonas foetus. Components detected in hydrogenosomes and in intact cells by electron paramagnetic resonance spectrometry. Mol. Biochem. Parasitol. 2, 39-50 (1980)

18. ORME-JohnSON, W.H. \& N.R. ORME-JOHNSON: Iron-sulfur proteins: The problem of determining cluster type. In: Iron-Sulfur Proteins. Spiro T.G., ed., John Wiley \& Sons, New York, pp. 67-96 (1982)

19. Read, C.P. \& A.H. Rothman: Preliminary notes on the metabolism of Trichomonas vaginalis. Am. J. Hyg. 61, 249-260 (1955)

20. ReEves, R.E.. J.D. Guthrie \& P. LOBELLE-RICH: 
Entamoeba histolytica: Isolation of ferredoxin. Exp. Parasitol. 49, 83-88 (1980)

21. RupP, H., K.K. RaO, D.O. Hall \& R. CAMMaCK: Electron spin relaxation of iron-sulphur proteins studied by microwave power saturation. Biochim. Biophys. Acta 537, 255-269 (1978)

22. Suhara. K. S. Takemori \& M. Katagirl: Improved purification of bovine adrenal iron-sulfur protein. Biochim. Biophys. Acta 263, 272-278 (1972)

23. Tanaka. M.. T. Nakashima, H.F. Mower \& K.T.
YASUNOBU: The C- and N-terminal amino acid sequences of Clostridium pasteurianum ferredoxin. Arch. Biochem. Biophys. 105, 570-574(1964)

24. Yasunobu, K.T. \& M. TANAKA: The types, distribution in nature, structure-function, and evolutionary data of the iron-sulfur proteins. In: Iron-Sulfur Proteins. Vol. II, Molecular Properties. W. Lovenberg ed., Academic Press, New York, pp. 27-130 (1973)

25. YoCH, D.C. \& R.P. CARITHERS: Bacterial iron-sulfur proteins. Microbiol. Rev. 43, 384-421 (1979) 